\title{
2003年十勝沖地震における杭の実被害調査とその解析的検討 FIELD INVESTIGATION AND ANALYSES STUDY ON PILE DAMAGE OF THE TOKACHI-OKI EARTHQUAKE IN 2003
}

\author{
古山田 耕司*1, 宮 本 裕 司*2, 福田 孝晴*3 \\ Kohji KOYAMADA, Yuji MIYAMOTO and Takaharu FUKUDA
}

\begin{abstract}
Super structure and pile foundation of Konan junior high school were severely damaged by the Tokachi-oki Earthquake, September 26, in 2003. The objective of this study is to investigate the damage by earthquake response analyses. The analyses of the structure on pile foundation are conducted using a numerical model taking into account an effect of soil nonlinearity. The observed strong motions in the borehole array at Atsuma Site by KiK-net are employed as an input motion to the soil-pile foundation-structure system. It is found that the super-structure had a lot of shear cracks by differential settlements induced by the compression failure at the pile head, and that the pile foundation damage at the pile head was caused not only by inertial forces of the super-structure but also by large soil displacements in very soft silt layer.
\end{abstract}

Keywords: The Tokachi-oki Earthquake, Pile Damage, Response Analyses, Cross Interaction, Pile Stresses, KiK-net 十勝沖地震, 杭被害, 応答解析, 相互作用, 杭応力, KiK-net

\section{1. はじめに}

2003 年 9 月 26 日に発生した十勝沖地震は、震源に近い日高地 方と十勝地方を始め、北海道全域に多大な被害を及ぼした。本地震 は、プレート境界で発生したマグニチュード 8.0 の地震であり、広 範囲で大きな摇れが観測された点が特徵といえる。

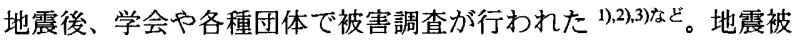
害の特徵は、マグニチュードの割に建築物の被害が比較的軽微であ ったが、札幌や北見といった震源から遠く離れた位置でも被害が発 生したことが挙げられる。また苫小牧港に建つ原油及びナフサタン クでは、大規模な火災が発生した。この原因として長周期地震動に よるスロッシングの影響が考元られており、現在も被害要因につい て検討されている ${ }^{4}$ 。

北海道勇払郡厚真町に建つ厚南中学校では、上部構造に多数の せん断ひび割れが発生し不同沈下が確認された。地震後、杭頭部の 掘出し調查を行った結果、多数の杭の杭頭が圧壊したことが判明し た 5)。また本地震は、K-NET や KiK-net といった全国規模の強震観
測網が設置されて以来、初めて発生したマグニチュード 8 級の地震 であり、多くの強震記録が得られている。厚南中学校の敷地内でも KiK-net によって地震観測が行われており、鉛直アレ一記録が観測 された 6)。

本論文では、まず RC 造 3 階建て校舎の上部構造と杭基礎の被 害調査結果を報告する。被害調査は地震直後に、上部構造の傾き、 床レベルの傾斜、外壁及び柱梁のひび割れの計測を行った。杭基礎 については、杭頭部の掘出し調査、IT 試験、ボアホールカメラに よる観察を行った。また杭被害の奏状をさらに検討するため、被害 杭の引抜きを実施し被害状況を詳細に調査した。

続いて、被害要因を解析的に検討するため地盤-杭基礎-上部構造 一体モデルによる応答計算を行った。応答計算では、まず KiK-net による鉛直アレー強震記録のシミュレーション解析を行い、地盤応 答の評価を行った。次に、中学校校舎の上部構造と杭体の非線形性 を考慮した地震応答解析を行い、計算結果と被害状況との対応関係 について検討した。
本論文は，文献14)の内容に加筆してまとめたものである。

*1 鹿鼠建設㑣小堀研究室 主任研究員

*2 鹿島建設株小堀研究室 部長・ I 博

*3 鹿畾建設侏建築設計本部グループリーダ
Senior Research Eng., Kobori Research Complex, Kajima Corp. General Manager, Kobori Research Complex, Kajima Corp., Dr. Eng. Group Leader, Architectural Design Division, Kajima Corp. 


\section{2. 十勝沖地震の諸元及び上部構造と杭基礎の概要}

図 1 に、2003 年十勝沖地震の震央と厚南中学校(KiK-net による 観測点:厚真)の位置を示す。地震は、2003 年 9 月 26 日午前 4 時 50 分、釧路沖深さ約 $42 \mathrm{~km}$ で発生した。気象庁マグニチュードは 8.0、 最大震度は 6 弱を記録した。KiK-net 観測点(厚真)との震央距離は 約 206km である。地震観測は地表と GL-153m で行われており、最 大加速度(EW)は GL-153m で $53 \mathrm{~cm} / \mathrm{s}^{2}$ 、地表で $376 \mathrm{~cm} / \mathrm{s}^{2}$ であった。

図 2 に、厚南中学校の配置図を示す。本中学校の校舎棟は RC 造の 3 階建て(建築面積 $925 \mathrm{~m}^{2}$, 延床面積 $2400 \mathrm{~m}^{2}$ )であり、竣工は 1980 年であった。KiK-net 観測点は校舎棟から約 $50 \mathrm{~m}$ 離れた地点 にあり、北西部に位置する。図 3 に、敷地内の 2 箇所で奏施された 標準貫入試験結果と杭の位置関係を示す。杭は、AHS 杭の A 種(PC 鋼材の直径は $7.1 \mathrm{~mm}$ 、プレストレス量は $4 \mathrm{MPa}$ )である。現在の $\mathrm{PHC}$ 杭に比べて PC 鋼材の直径が $0.3 \mathrm{~mm}$ 細いが、両者の耐震性能は殆 ど同じである。杭径は $40 \mathrm{~cm}$ 、杭頭之杭先端は各々 GL- $1.5 \mathrm{~m}$ と GL-30m である。杭頭の接合条件は、フーチングへの埋込みが $5 \mathrm{~cm}$ で、基礎下端から $50 \mathrm{~cm}$ 中詰め補強されている。また杭は長さ $15 \mathrm{~m}$ のものを 2 本あるいは、長さ $10 \mathrm{~m}$ のものを 3 本継いで施工されて いた。敷地地盤は、地表から GL-30m まで軟弱層が堆積しており、 土質は泥炭層及びシルト㸴から構成される。2箇所での地盤調查結 果はほぼ同じであり、校舎位置は概ね成層地盤と考えられる。

\section{3. 上部構造の被害調查}

上部構造の被害調査は、地震㨁後に、(1)建物の傾き、(2)木レベ ルの沈下、(3)外壁と柱梁のせん断ひび割机について計測を行った。

図 4 に、建物の傾きと床レベルの計測結果を示す。建物の最大 倒れは北東隅の $56 \mathrm{~mm}$ であり、最大傾倒角は 1/220であった。床 レベルの最大沈下量は $110 \mathrm{~mm}$ であり、床の傾きは最大 $1 / 160$ (X6-X7 通り間)であった。

図 5 に外壁(北面)のひび割れ位置を、写真 1 に最大ひび割れが 生じた部分の被害状況を示す。外壁のせん断ひび割㧈は、X6-X7 通り間に集中している。これは、図 4 に示した不同沈下による。 また最大ひび割れは同箇所で生じている。ひび割れは、最大幅が $6 \mathrm{~mm}$ 、ひび割れ長さは $1 \mathrm{~m}$ であった。以上の被害調査の結果、上 部構造は全壊と判定された。

\section{4. 杭基礎の被害調查}

杭基礎の被害調査は、(1)杭頭部の掘出し調査、(2)T 試験および、 (3)ボアホールカメラによる観察を行った。また杭被害の実状を詳 細に把握するため、地震後約 9 ヶ月経った段階で杭の引抜き調査 を実施した。

\section{1 杭頭部の掘出し調查}

杭頭部の掘出し調査は、講堂棟を含む計 7 本の杭(図 2 参照)に ついて実施した。写真 2 に、校舎棟の北東隅杭(No.1)の杭頭部の掘 出し状況と杭頭の被害状況を示す。校舎棟の掘出し調查を行った 杭はいずれも、杭頭部で圧壊および曲げひび割れが確認された。 一方、講堂棟の杭は部分クラックのみで圧壊に至ったものがなく、 いずれの杭頭も被害が小さかった。

4.2 IT 試験およびボアホールカメラによる観察
地中部での被害状況を確認するため、杭側面にセンサと打撃用 ブロックを取付け、ハンマで吅くことにより IT 試験を塞施した。 表 1 に、IT 試験による測定結果を示す。曲げひび割れは、杭頭部 (GL-6m 以浅)に集中している。さらに梁い位置の杭被害を確認す るため、ボアホールカメラによる杭体内部の観察を実施した。観 察は、カメラが挿入可能な講堂棟の No.5 杭について行った。図 6 に、ボアホールカメラによる調查結果を示す。部分的な曲げひび 割れが杭頭と GL-5.7m で確認され、IT 試験結果と概ね対応した。 ボアホールカメラでは GL-20m まで調査可能であったが、それ以 深は杭体内に浸水した地下水の影響で透明度が悪くなり観察でき なかった。

\section{3 杭の引拔き調查}

杭被害を詳細に検討するため、南東隅杭(No.2 杭、図 2 参照)の 引抜き調査を実施した。杭の引抜きは、杭体への影響をできるだ け少なくするため $\mathrm{KJ}$ 工法》により行った。 $\mathrm{KJ}$ 工法は、鋼製ケー シングにより杭周地盤を掘削し、杭と地盤の摩擦を切ることによ り無振動で杭を引抜く工法である。写真 3 に杭の引抜き状況を、 また写真 4 に引抜き杭の全景を示す。引抜き杭は試験杭であった ため、杭周には当時記された打設梁さ計測用の目盛が残っていた。 また長さ $15 \mathrm{~m}$ の杭を 2 本継いだものであり、継ぎ手部や杭先端閉 塞部の鋼製治具に錆は見られず、杭体の状態は良好であった。

引拢き杭の被害調査を行った結果、GL-20m 付近で大きな曲げ ひび割れが確認できた。写真 5 に GL-20m 付近のひび割れ状況を、 また図 7 にひび割れのスケッチを示す。GL-20m 付近には、 GL-20.0m、-20.3m、-20.5m の 3 简所で曲げひび割れが生じていた。 GL-20.3m のひび割れが最も大きく、ひび割れ幅は最大 $1.0 \mathrm{~mm}$ で あり、全周に同程度の損傷がみられた。また写真 6 に示すように GL-20.3m 部分を切出し、内側のひび割れを確認した。その結果、 杭内側にも最大幅 $0.5 \mathrm{~mm}$ の曲げひび割れが全周に生じていること がわかった。なお GL-20.0m と-20.5m のひび割れは、幅 $0.1 \mathrm{~mm} の$ 微小クラックであった。

以上の調査結果から、本中学校校舎は杭頭部圧壊に伴う不同沈 下により上部構造にせん断ひび割れが多数生じたこと、GL-20mの 地中部にも杭被害が生じていたことを確認した。

\section{5. 応答解析による杭被害の検討}

杭基礎の被害について解析的に検討を行う。杭基礎の応答解析 では、地盤の応答を適切に評価する必要がある。本中学校敷地で は前述のとおり、KiK-net による鉛直アレ一記録が得られている。 本検討では、まず観測記録のシミュレーション解析を行い、地盤 応答を評価する。次に、杭基礎-上部構造の応答解析を赛施し、杭 被害について検討する。

\section{1 地盤-杭基礎-上部構造の応答解析モデル}

地盤応答の解析は、地盤剛性の歪み依存性を考虑した時刻歷非 線形解析 ${ }^{8)}$ により行った。表 2 に地盤定数を示す。地盤層序と $\mathrm{S}$ 波速度は、KiK-net 観測点での地盤調査結果より設定した。但し、 GL-18m 以浅の土質については、中学校校舎位置でのボーリング調 査結果をもとに泥炭とシルト層とした。図 8 に、地盤の非線形特 性( $\mathrm{G} \sim \gamma, \mathrm{h} \sim \gamma$ 曲線)を示す。地盤の非線形性は、既往の室内試験 


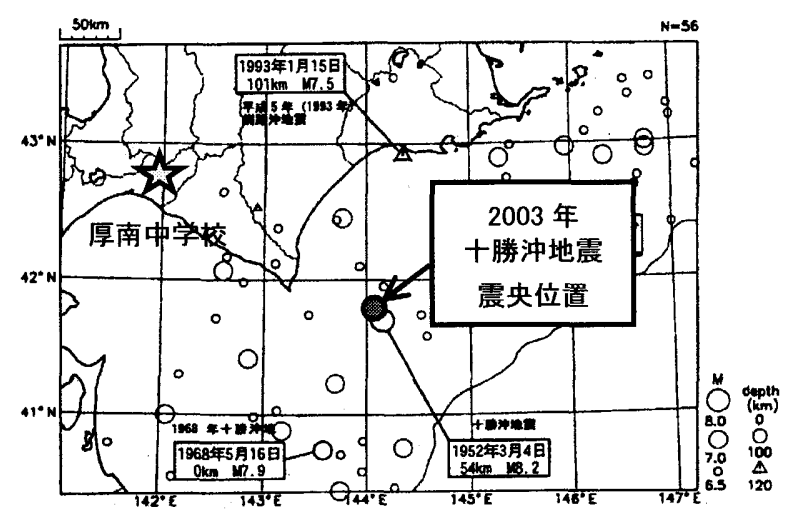

図 1 地震の震央と厚南中学校の位置

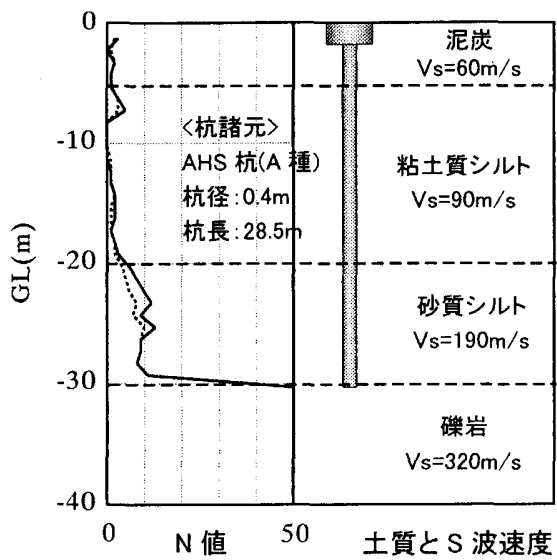

図 3 標準貫入試験結果と杭の関係

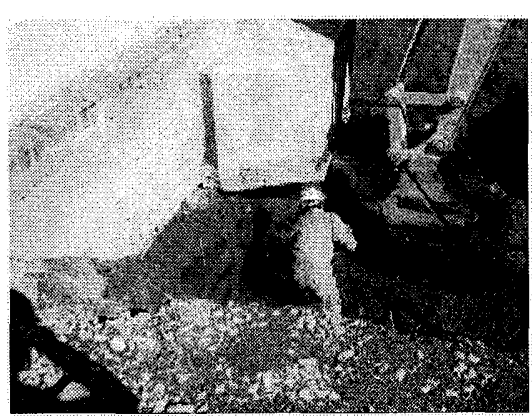

(掘出し状況)

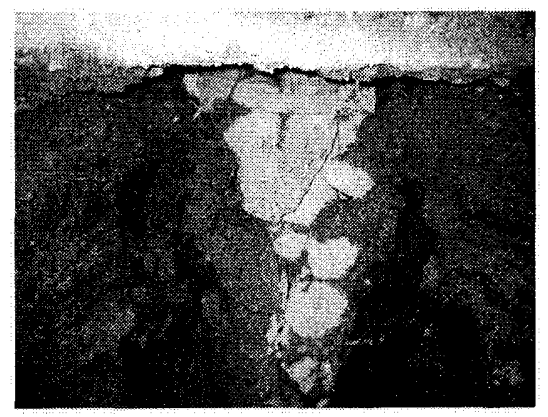

(被害状況)

写真 2 校舎棟の北東隅杭(No.1 杭)の掘出し調査

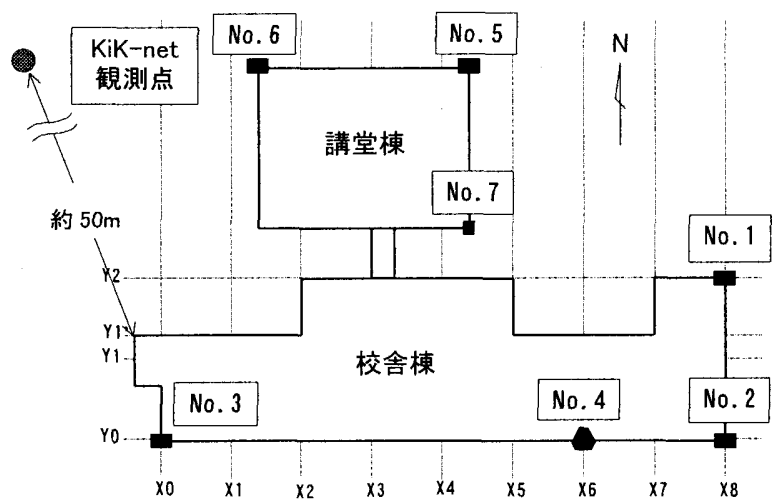

図 2 校舎棟亡講堂棟の配置図および地震観測点の位置関係 （図中の No.は被害調查を行った杭番号）

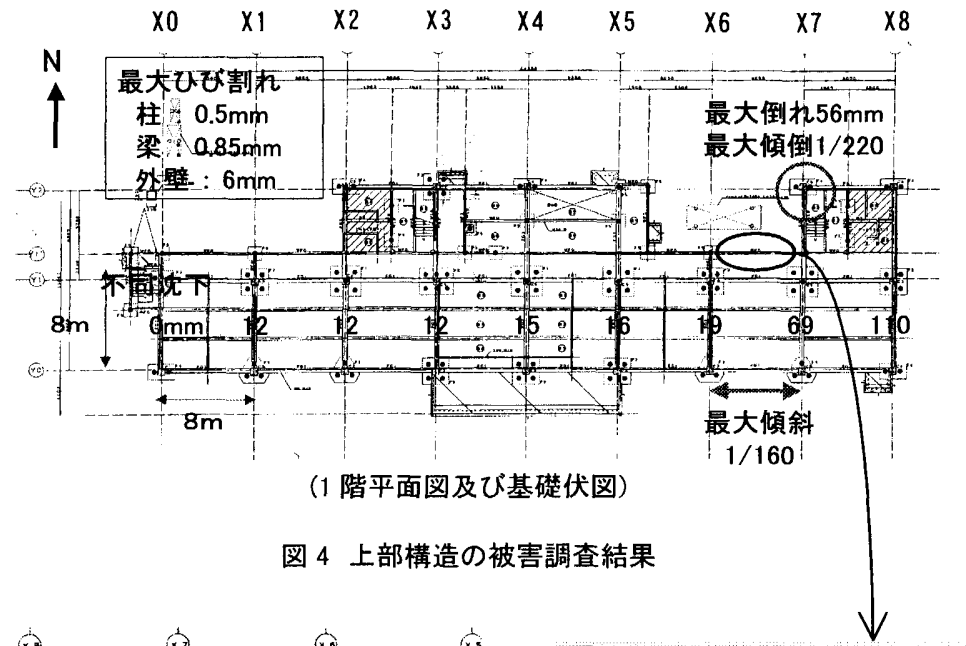

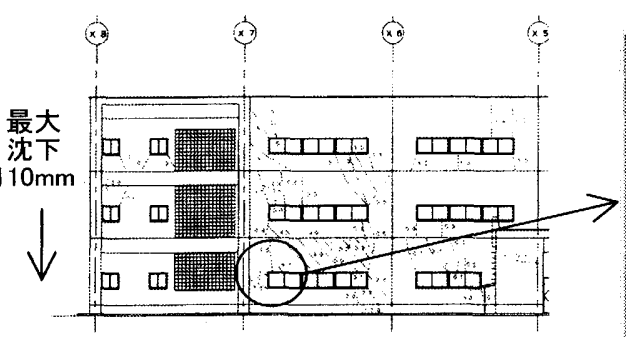

図 5 外壁(北面)のひび割れ調査結果

表 1 IT 試験による杭被害の調查結果

\begin{tabular}{|c|c|c|}
\hline 杭番号 & $\begin{array}{c}\text { クラック位置 } \\
\mathrm{CL}(\mathrm{m})\end{array}$ & $\begin{array}{c}\text { 先端反射位圆 } \\
\mathrm{GL}(\mathrm{m})\end{array}$ \\
\hline 1 & 4.6 & (不明瞭) \\
\hline 2 & 3.4 & (不明瞭) \\
\hline 3 & 4.0 & (不明瞭) \\
\hline 4 & 4.7 & (不明瞭) \\
\hline 5 & 6.0 & (不明瞭) \\
\hline 6 & 5.0 & 30.8 \\
\hline 7 & $5.2,9.0$ & 32.2 \\
\hline
\end{tabular}

$\mathrm{GL}-5 \mathrm{~m}$

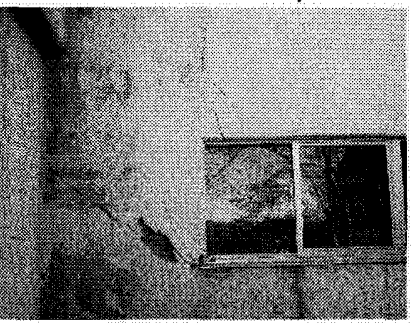

写真 1 上部構造の被害状況

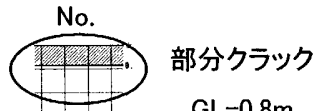

$\mathrm{GL}-0.8 \mathrm{~m}$

$\mathrm{GL}-5.7 \mathrm{~m}$

GL-10m

GL-15m

$\mathrm{GL}-20 \mathrm{~m}$

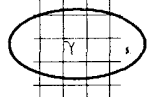

杭内水位

(調査終了)

図 6 ボアホールカメラによる調査結果 (講堂棟 No.5 杭) 


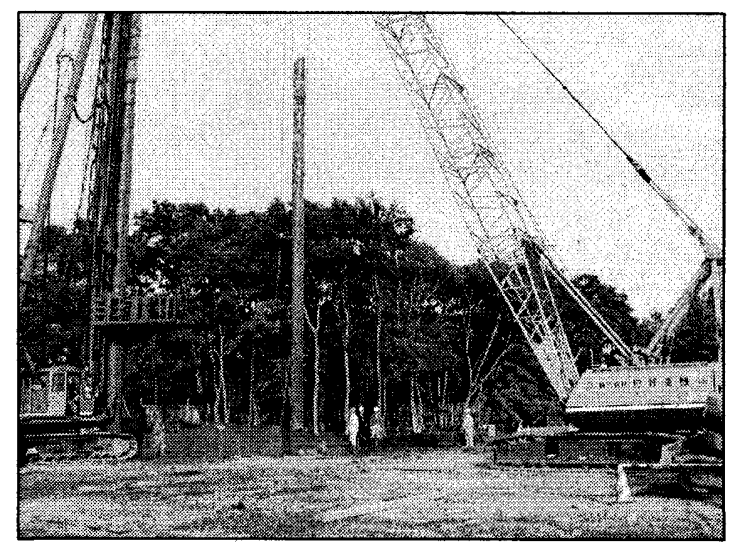

写真 3 南東隅杭(No.2 杭の上杭)の引抜き状況

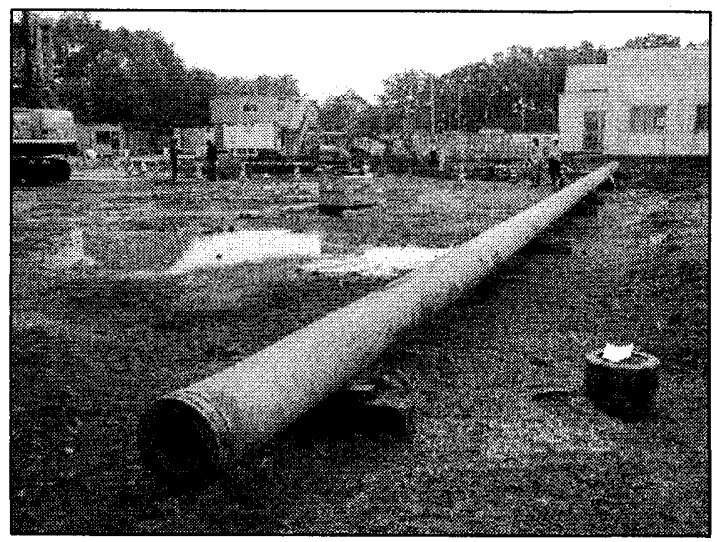

写真 4 引抜き杭の全景(手前が杭先端)

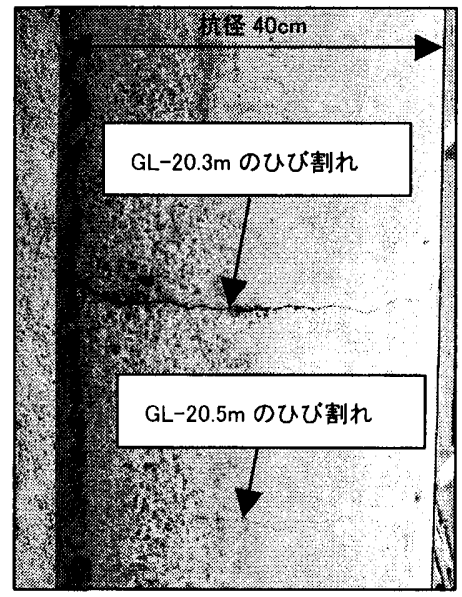

写真 5 GL-20m 付近のひび割れ状況

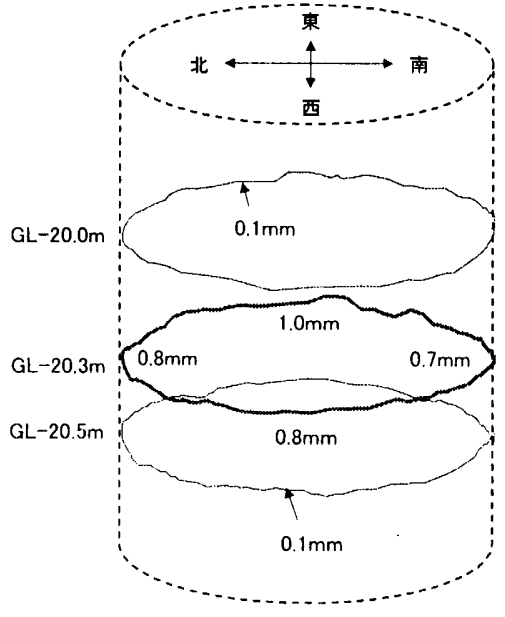

図 $7 \mathrm{GL}-20 \mathrm{~m}$ 付近のひび割れのスケッチ

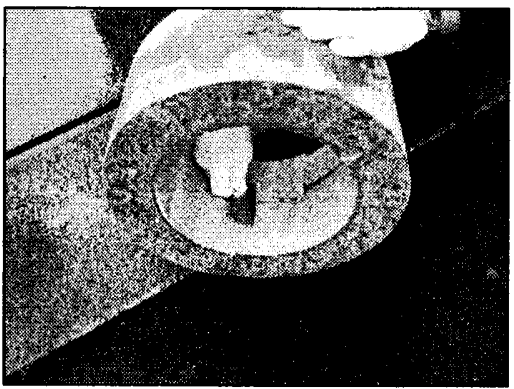

写真 6 GL-20.3m の杭内側のひび割れ状況 (ダイアモンドカッタで杭を切出し、ひび割れ 幅の計測を行った)
結果 9)をもとに土質特性や拘束圧を考慮して設定した。また被害 調査結果より液状化の影響は小さいものと考え、本解析では有効 応力の変動を考慮しない。なお GL-76m 以深は線形とした。入力 は、地中(GL-153m)での水平 2 方向の観測記録を同時入力した。

図 9 に、杭基礎-上部構造の応答解析モデルを示す。応答計算は、 上部構造と杭基礎を一本の多質点曲げせん断棒にモデル化し、杭 の各質点に群杭効果を考慮した相互作用ばねを取り付けたモデル

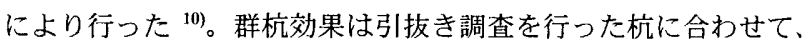
同じフーチングで繋がれた 2 本杭をモデル化し計算を行った。応 答解析では、相互作用ばねを介して観測記録のシミュレーション 解析から得られた自由地盤の各深さでの応答を入力し、時刻歷計 算を行う。相互作用ばねの初期定数は、自由地盤の店答解析から 得られた等価地盤定数を用いて算定する ${ }^{10}$ 。相互作用ばねには、 杭と地盤との相対変位により生じる非線形性を考慮する。基礎底 面の回転ばねは、杭先端地盤と杭の軸剛性から単杭の上下ばねを 求め、群杭の回転ばね定数を算定し線形とした。解析は、観測記 録の計算刻み $\Delta \mathrm{t}=0.005$ 秒を 4 分割し、150 秒間(120,000 ステップ) の応答計算を行った。

表 3 に、上部構造の解析定数を示す。解析では、上部構造の長 辺(EW)方向と短辺(NS)方向の応答計算を別々に行った。上部構造
の各層の剛性は、文献 11)をもとに基礎固定時の固有周期が 0.3 秒 となるように設定した。上部構造の終局耐力 $Q u$ は、当該建物の耐 震診断結果(2 次診断)をもとに設定した。上部構造の非線形モデル は、層毎に 3 折れ線モデルの Degrading Tri-linear ${ }^{12}$ にに近似した。骨 格曲線の第 1 折れ点は各層のせん断耐力が終局耐力 $\mathrm{Qu}$ の $1 / 2$ とな る点、第 2 折れ点は層間変形が $1 / 250$ となる点とする。また第 3 剛性は、初期剛性の 1/100 とする。NS(短辺)方向は、耐震壁を考慮 して弾性とした。減衰は瞬間剛性比例型とし、1 次周期に対して 3\%を与えた。

杭体は曲げのみに非線形性を考慮した。曲げモーメントM一曲 率 $\phi$ の関係は、長期軸力 $(440 \mathrm{kN})$ を考慮し、コンクリートと PC 鋼 材の応力ーひずみ関係に非線形特性を与え、断面の平面保持の仮 定に基づいたファイバモデルの静的漸増解析から求めた ${ }^{13)}$ 。コン クリートの設計基準強度は $80 \mathrm{MPa}$ とし、 $\mathrm{PC}$ 鋼材は降伏点強度を $1,300 \mathrm{MPa}$ 、引張強度を $1,450 \mathrm{MPa}$ とした。復元力特性は、上部構 造と同様に 3 折れ線モデルの Degrading Tri-linear に近似した。骨 格曲線の各折れ点は、第 1 折れ点が曲げひび割れ発生点、第 2 折 れ点は PC 鋼材の降伏点、第 3 折れ点は縁コンクリートが圧壞に達 するか、または PC 鋼材の引張歪みが 5\%に達する点とした。図 10 に、ファイバモデルによる杭体のM- - 関倸と応答解析に用いた 
表 $2 \mathrm{KiK}$-net 観測点と校舎位置の地盤定数

\begin{tabular}{|c|c|c|c|c|c|c|c|}
\hline 倠睍測点 & KiK-net & 涀測点 & 中学校枉 & 舎位置 & & & \\
\hline 地表 & $\begin{array}{c}\text { 深度 } \\
\mathrm{GL}(\mathrm{m})\end{array}$ & $\begin{array}{l}\text { 層厚 } \\
(\mathrm{m})\end{array}$ & \begin{tabular}{c|} 
深度 \\
$\mathrm{GL}(\mathrm{m})$
\end{tabular} & $\begin{array}{c}\text { 層厚 } \\
(\mathrm{m})\end{array}$ & 土質 & $\begin{array}{c}\begin{array}{c}V s \\
(\mathrm{~m} / \mathrm{s})\end{array}\end{array}$ & $\begin{array}{c}V p \\
(\mathrm{~m} / \mathrm{s})\end{array}$ \\
\hline & 2 & 2 & 6 & 6 & 泥炭 & 60 & 160 \\
\hline & 18 & 16 & 20 & 14 & シルト & 90 & 400 \\
\hline & 28 & 10 & 30 & 10 & 砂 & 190 & 950 \\
\hline & 40 & 12 & 40 & 10 & 磷岩 & 320 & 1590 \\
\hline & 52 & 12 & 52 & 12 & 泥岩 & 210 & 1590 \\
\hline & 76 & 24 & 76 & 24 & 砂岩 & 310 & 1590 \\
\hline & 132 & 56 & 132 & 56 & 磷岩 & 430 & 1730 \\
\hline & 153 & 21 & 153 & 21 & 砂岩 & 520 & 1730 \\
\hline & - & - & $\ldots$ & - & 砂岩 & 520 & 1730 \\
\hline
\end{tabular}

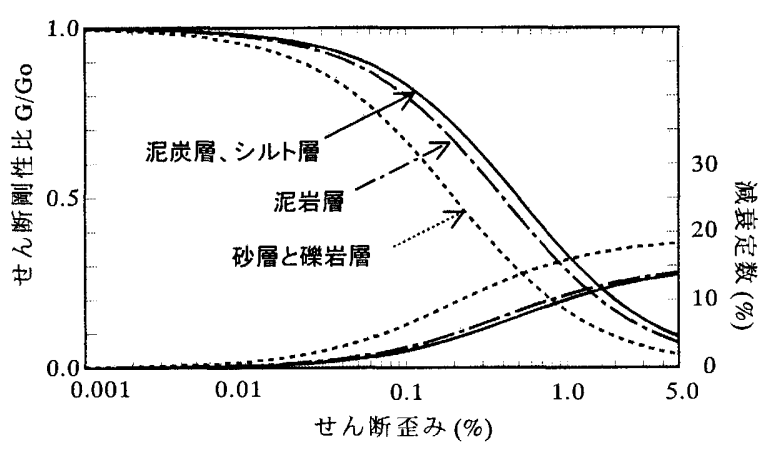

図 8 地盤の $G \sim \gamma 、 h \sim \gamma$ 曲線

3 折れ線モデルを示す。また同図には、後述する応答解析の結果 から得られた最大軸力時 $(800 \mathrm{kN})$ と最小軸力時 $(-10 \mathrm{kN})$ での非線形 モデルについても比較して示す。

\section{2 観測記録のシミュレーション結果}

図 11 に、地表の加速度波形と応答スペクトル(EW 方向と NS 方 向，減衰 5\%)を示す。また同図には、各 1 方向入力時の応答スペク トルも比較して示す。観測記録の応答スペクトルは、EW 方向ともに周期約 2 秒に大きな振幅が見られる。水平 2 方向同時 入力した解析結果は、 1 方向入力時に比べて観測記録の周期特性

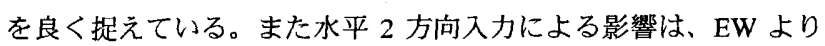
NS 方向の応答で顕著にみられる。これは強軸(EW)方向の応答に よる地盤の非線形化が、弱軸(NS)方向の振動性状に影響を与えた ことによる。

図 12 に、各深度での地盤の応答スペクトル(EW 方向、減衰 5\%) を比較して示す。周期 2 秒の成分は、GL-153m から地表に向かい 増幅し、地表のスペクトル振幅は GL-20m での振幅の約 3 倍にな っている。これより、本地点では GL-20m のシルト層以浅の軟弱 層が周期 2 秒で大きく増幅したことがわかる。

図 13 に、地盤応答の深度分布を EW 方向と NS 方向について比 較して示す。ここでは、校舎位置での地盤層序に解析モデルを修 正し応答計算を行っている。地盤変位は、全深度で EW 方向の方 が NS 方向より大きく、GL-20m 以浅のシルト層で大きく増幅する。 地盤のせん断歪みは GL-6m と-20m 付近で大きく、EW 方向では 各々 $2 \%$ と $3 \%$ になる地盤剛性は歪みに応じて低下し、EW 方向で は GL-20m 付近で初期剛性の約 $1 / 5$ になる。

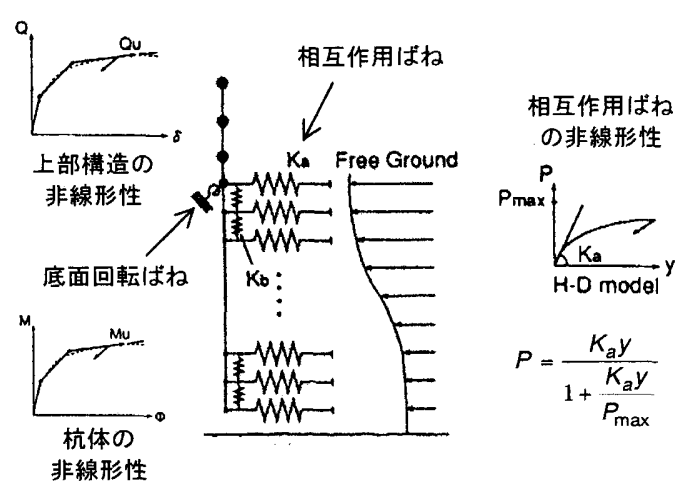

図 9 上部構造と杭基礎の解析モデル

表 3 上部構造の解析定数

\begin{tabular}{|c|c|c|c|c|c|c|}
\hline 階 & $\begin{array}{c}\text { 階高 } \\
(\mathrm{cm})\end{array}$ & $\begin{array}{c}\text { 重量 } \\
(\mathrm{kN})\end{array}$ & $\begin{array}{c}\text { 初期剛性 } \\
\mathrm{K} 1(\mathrm{kN} / \mathrm{cm})\end{array}$ & $\begin{array}{c}\text { 第1折れ点 } \\
\text { でのせん断 } \\
\text { カQ1 }(\mathrm{kN})\end{array}$ & $\begin{array}{c}\mathrm{N} \text { 第2剛性 } \\
K 2(\mathrm{kN} / \mathrm{cm})\end{array}$ & $\begin{array}{c}\text { 終局耐力 } \\
\mathrm{Qu}(\mathrm{kN})\end{array}$ \\
\hline 3 & 365 & 7110 & 15300 & 5150 & 4580 & 10300 \\
\hline 2 & 370 & 9140 & 14030 & 4720 & 4130 & 9440 \\
\hline 1 & 375 & 11090 & 24200 & 8130 & 6990 & 16270 \\
\hline
\end{tabular}

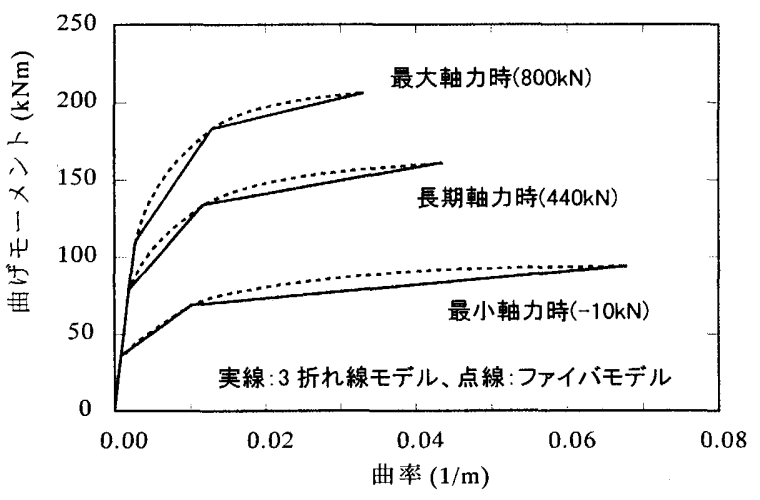

図 10 杭体の非線形特性

\section{3 上部構造の応答}

図 14 に、EW 方向と NS 方向の屋上階での応答スペクトル(減衰 5\%)と加速度波形を示す。また応答スペクトルには、杭体線形時の 結果も比較して示す。屋上階の最大加速度は、NS 方向に比べて EW 方向が大きく、EW では時刻 55 秒、NS では時刻 53 秒に生じ ている。応答スペクトルは、ほぼ全周期領域で EW 方向が NS 方 向より大きい。杭体線形時と杭体非線形を考慮した結果は殆ど差 がなく、杭体の非線形性が上部構造に与える影響は小さい。

図 15 に、EW 方向の屋上階と 1 階及び地表面の応答スペクトル (減衰 5\%)を示す。応答スペクトルは、周期 1 秒以下の短周期領域 では屋上階 > 1 階>地表面の順に応答が大きくなり、地盤-杭基礎上部構造連成系の固有周期(0.35 秒)付近で増幅する。一方、周期 1 秒以上の長周期領域では、1 階及び屋上階ともに地表面応答とほ ぼ同じ振幅レベルとなる。

図 16 に、EW 方向の最大応答值を 3 折れ線モデルに示す。応答 結果は 1 階と 2 階で第 1 折れ点を越えるが、最大層間変形は 1 階 

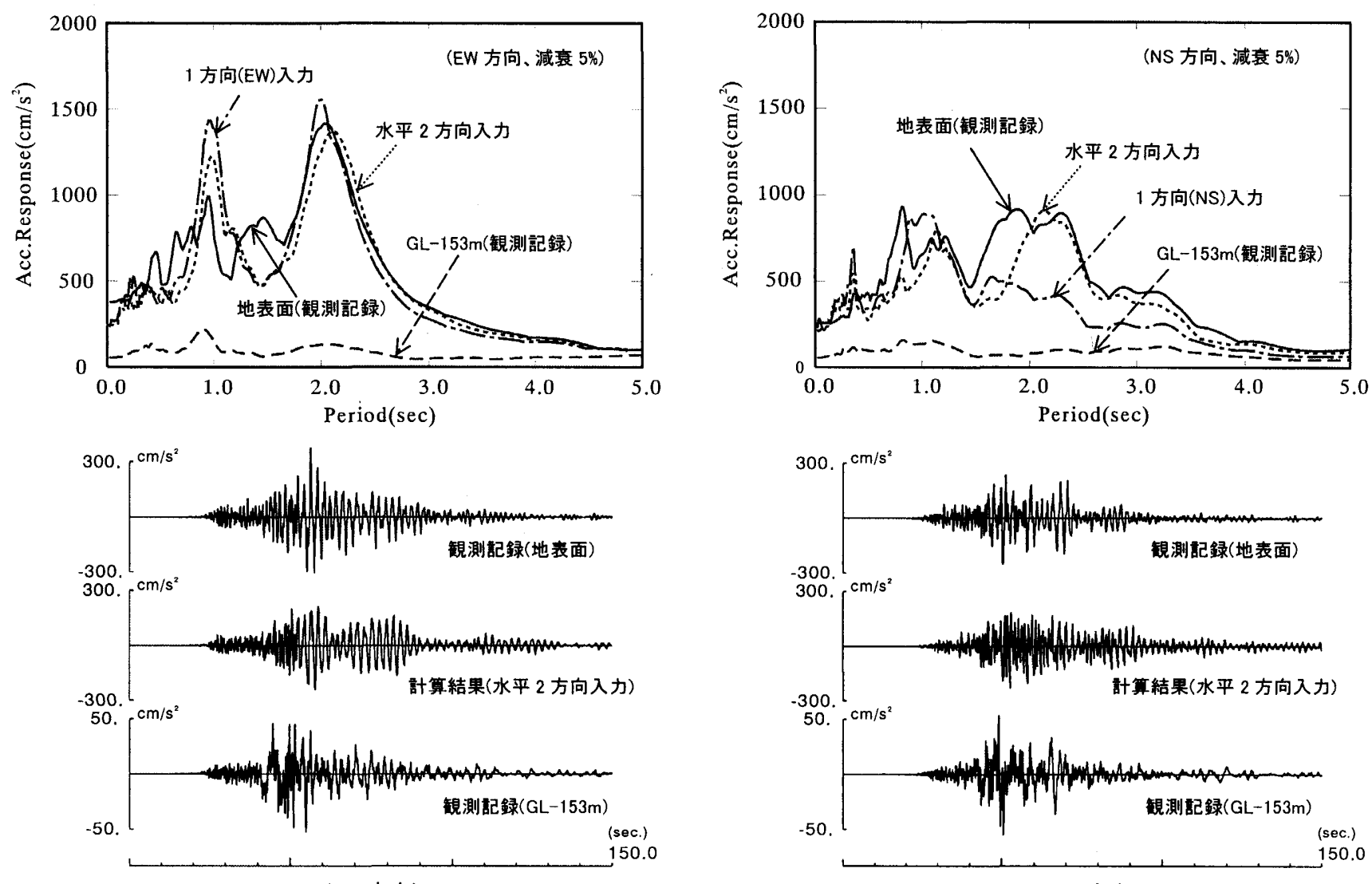

(EW 方向)

図 11 地表面での応答加速度と応答スペクトル(減衰 $5 \%$ )

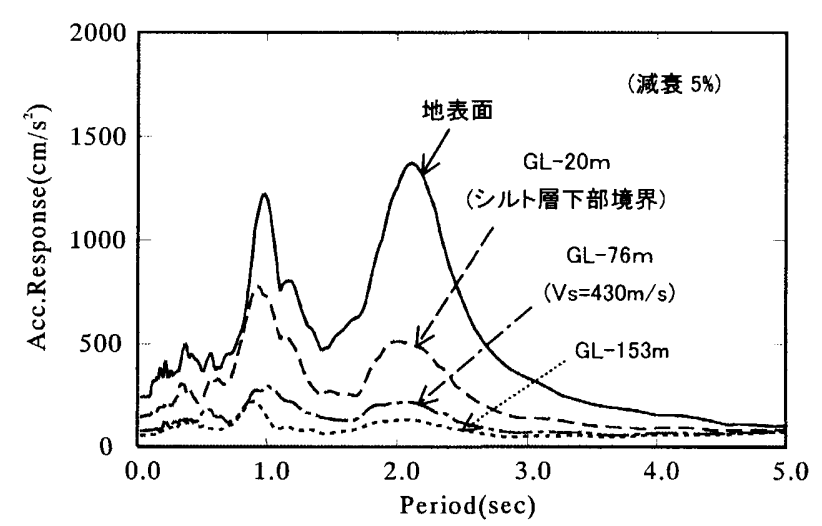

図 12 各深さでの応答スペクトル(EW 方向、減衰 5\%)
で $0.55 \mathrm{~cm}(1 / 682) 、 2$ 階で $0.60 \mathrm{~cm}(1 / 617)$ と小さく、最大せん断力は 終局耐力に比べて十分に小さい。これより上部構造のせん断ひび 割れは、地震時に生じたものではないことがわかる。

\section{4 杭基礎の応答}

図 17 に、杭体線形時と杭体非線形時における EW 方向と NS 方 向の最大杭応力分布を示す。また杭体非線形時の杭応力には、全 体系モデルによる杭応力(Total)に地盤震動のみによる杭応力 (Kinematic)を比較して示す。杭体線形時の杭応力は、両方向とも 杭頭とシルト層の下部境界付近(GL-20m)で大きくなる。杭体非線 形を考慮した場合は同筒所で、杭体線形時に比べて大きく応力が 低減する。また杭頭での応力は、上部構造の応答に対応して EW
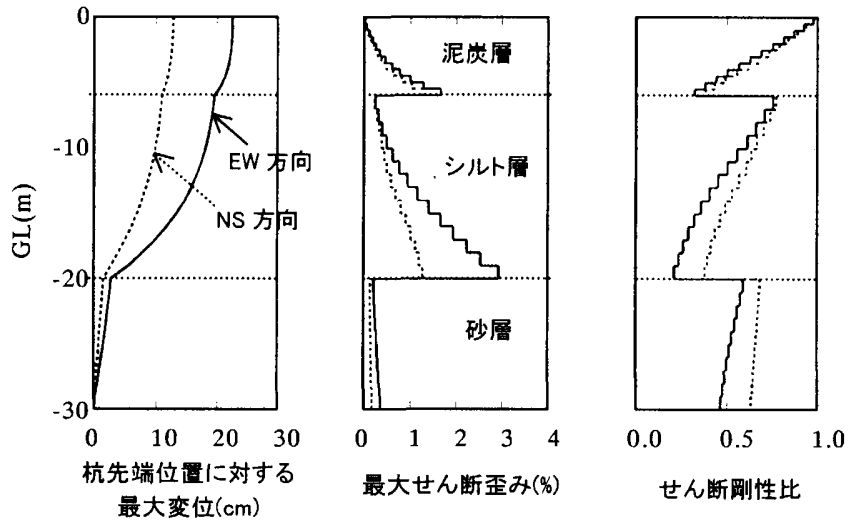

図 13 地盤応答の深度分布図

が NSより大きい。杭頭から約 GL-10m までの杭応力は、Kinematic 成分だけでなく上部構造からの慣性力(Inertial 成分)による影響が みられるが、それ以深は主に Kinematic 成分だけで生じている。

図 18 に、引抜き調查した杭(No.2 杭、南東隅杭)の杭頭での軸力 波形を示す。変動軸力は、同図に示す EW,NS 入力時の上部構造の 転倒モ一メントから換算した軸力を時刻歴で足し合せている。調 查杭の変動軸力は、主に NS (短辺)方向の回転振動により生じてい ることがわかる。また、杭体の非線形特性が変動軸力に依存する ことは良く知られている。その影響を確認するため、長期軸力 $(440 \mathrm{kN})$ から差引いて求めた最大軸力時 $(800 \mathrm{kN})$ と最小軸力時 $(-10 \mathrm{kN})$ での杭体非線形モデル(図 10 参照)による応答計算を行った。 

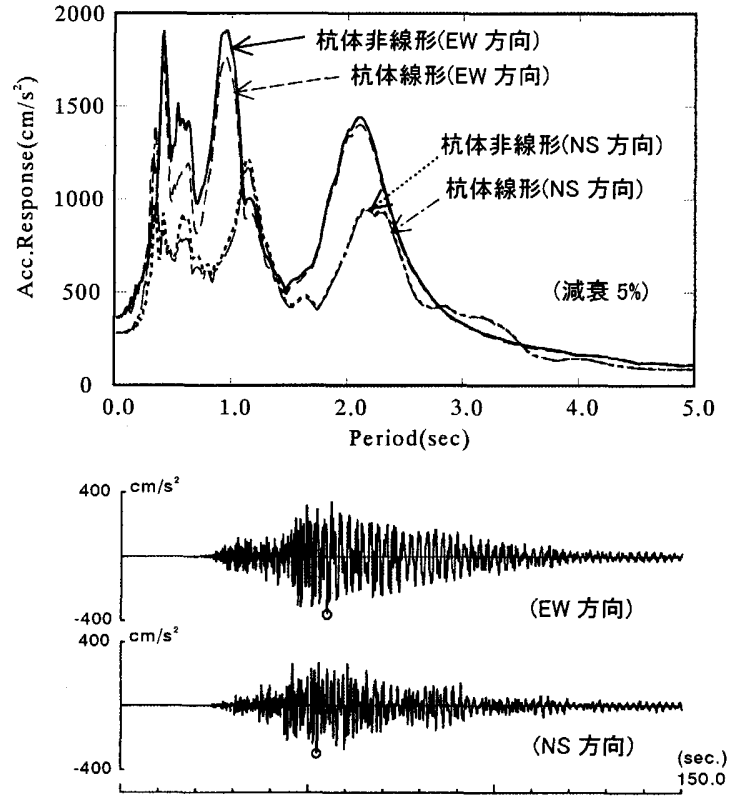

図 $14 \mathrm{EW}$ 方向と NS 方向の屋上階の 応答加速度波形と応答スペクトル(減衰 $5 \%$ )

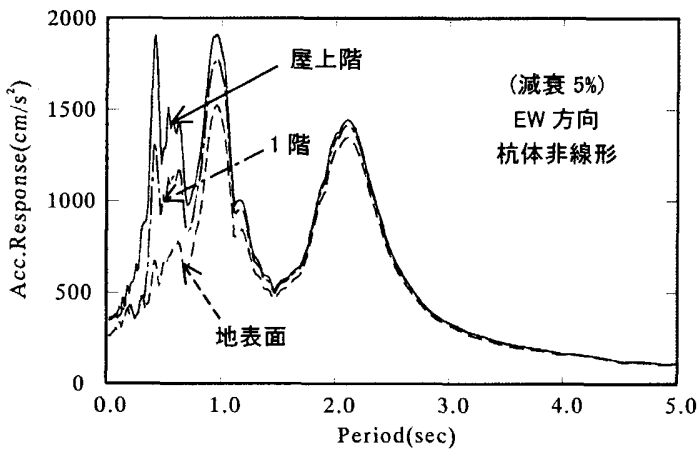

図 15 屋上階と 1 階と地表面での 応答スペクトル(EW 方向、减衰 $5 \%$

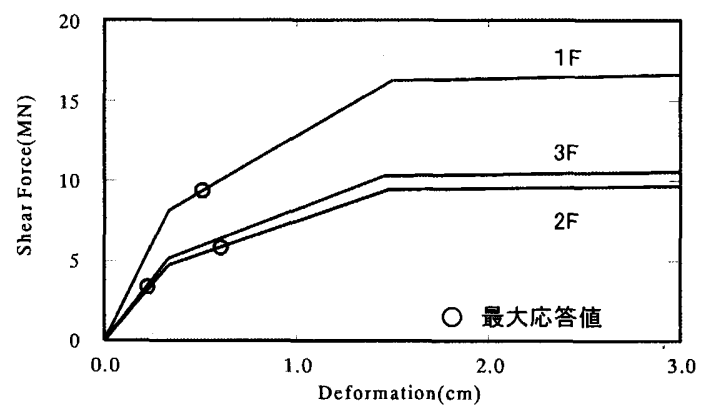

図 16 上部構造の最大応答值と3 折れ線モデル(EW 方向)

図 19 に、各軸力時の非線形モデルによる $\mathrm{EW}$ 方向の最大杭応 力と最大塑性率(第 2 折れ点に対する最大曲率の比)の深度分布を 比較して示す。軸力が小さいほど、杭の終局耐力が小さくなるた め最大塑性率は大きくなる。最小軸力時の最大塑性率は、杭頭で 約 6.0、GL-20m で約 3.0 となり、被害程度の差に概ね対応する。

図 20 に、最小軸力時の杭頭と GL-20m での曲率の応答波形(EW 方向)を示す。なお、変化の大きい時刻 30 130 秒までを示す。杭 頭の曲率は時刻 40 秒付近から大きくなり、時刻 55 秒で最大とな
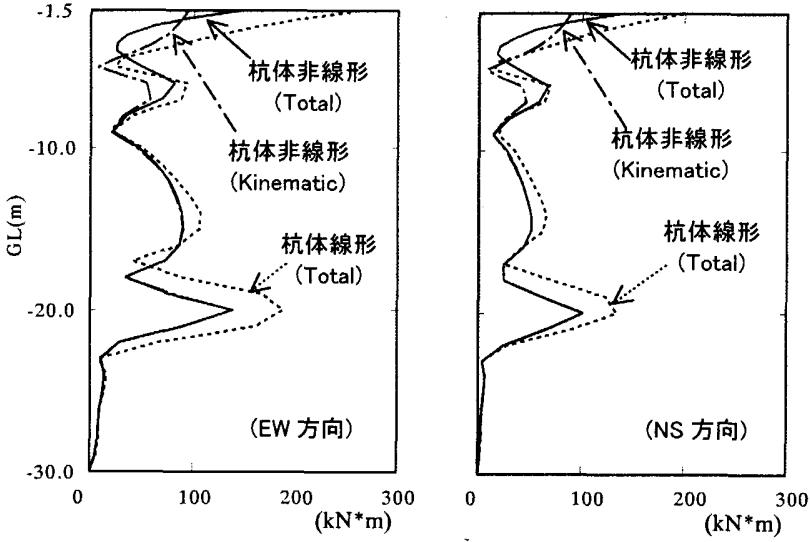

図 17 EW 方向とNS 方向の最大曲げモーメント分布

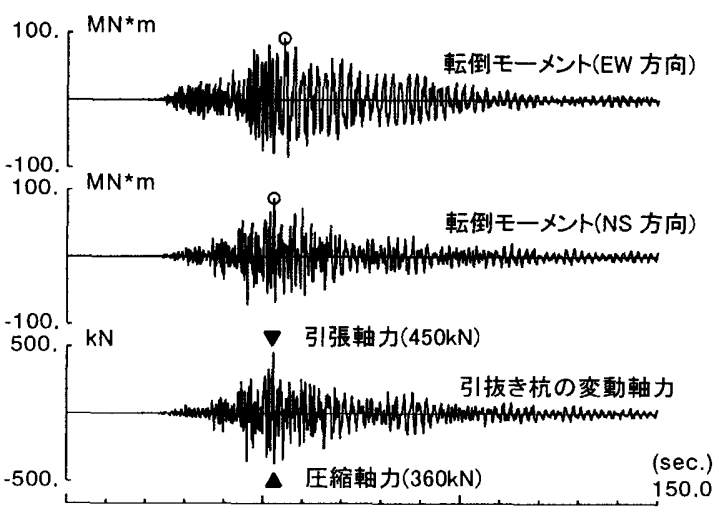

図 18 引抜き調査した杭(No.2 杭、南東隅杭)の変動軸力と 上部構造の転倒モーメント
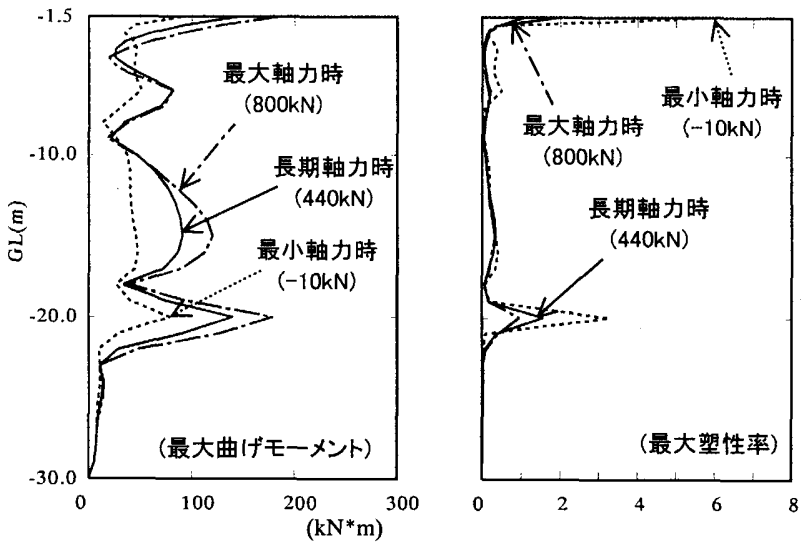

図 19 各軸力時の杭の最大曲げモーメントと 最大塑性率の深度分布(EW 方向)

る。これは、図 14 に示した上部構造の応答加速度が最大となる時 刻に対応する。一方、GL-20m での曲率は、時刻 50 秒付近から大 きくなり始めて時刻 58 秒で最大となり、杭頭部と塑性化状況が異 なる。これは図 17 に示したように、杭頭と GL-20m では、Inertial 成分と Kinematic 成分の影響が異なることによる。

図 21 に、最大軸力時(圧縮軸力時) と最小軸力時(引張軸力時)の 杭頭と GL-20m での M- $\phi$ 関係(EW 方向)を示す。最大軸力時の杭 頭の最大曲率は 0.014 であるのに対して GL-20m では 0.011 であり、 
両者に殆ど差が見られない。一方、最小軸力時の杭頭での最大曲 率は約 0.06 となり、終局点(0.068)近くにまで達する。また GL-20m の最大曲率も 0.03 程度になり、杭頭ほどではないが大きく塑性化 する。以上の検討より、杭頭は引張軸力時に大きく損傷(ひび割れ) が進み、最終的に圧壊に至ったことがわかる。また、引張軸力時 に生じた損傷度合いの違いが、杭頭と GL-20m に被害程度の差を 生じさせた一因であると考えられる。
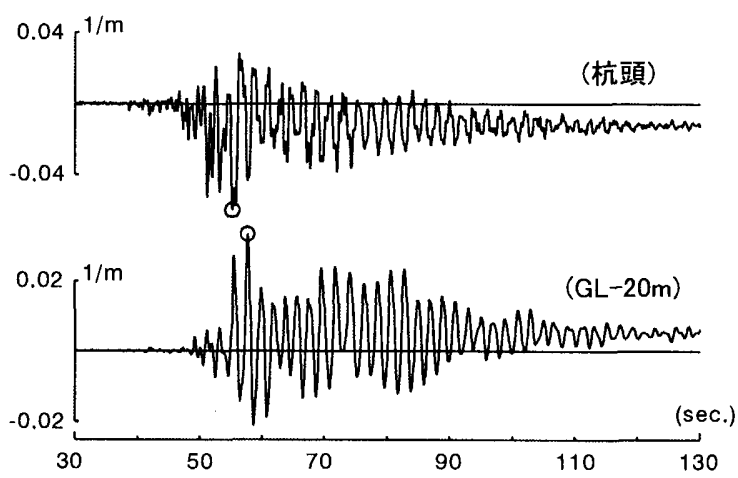

図 20 最小軸力時(-10kN)の杭頭と GL $-20 m$ での 曲率波形(EW 方向)
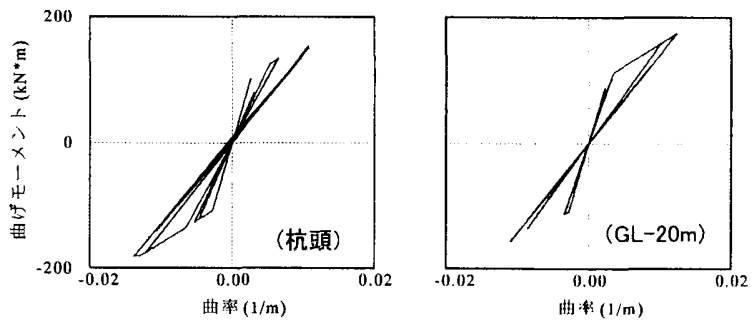

（最大軸力時の $M-\phi$ 関係）
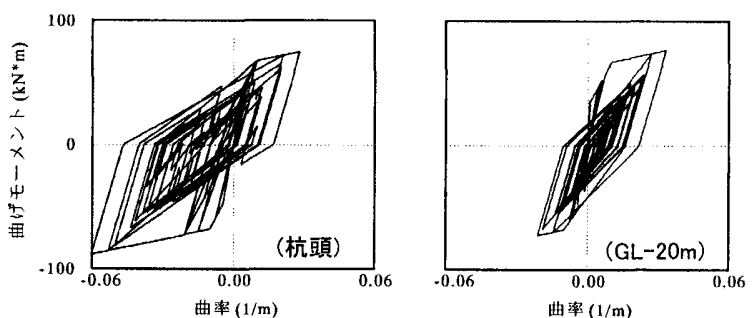

(最小軸力時の $\mathrm{M}-\phi$ 関係)

図 21 最大軸力時 $(800 \mathrm{kN})$ と最小軸力時 $(-10 \mathrm{kN})$ の 曲げモーメント $\mathrm{M}$ と曲率 $\phi$ 関係(EW 方向)

6. まとめ

2003 年十勝沖地震では、北海道厚真町の厚南中学校に大きな被 害が生じた。本研究では、詳細な被害調査と地盤-杭基礎-上部構造 の応答解析を実施し、被害要因について検討した。

（1）上部構造の被害は、最大倒れが北東隅で $56 \mathrm{~mm}$ 、最大傾倒角は 1/220 であった。床レベルの最大沈下量は $110 \mathrm{~mm}$ であり、床の傾 きは最大 $1 / 160$ であった。外壁のせん断ひび割れは最大 $6 \mathrm{~mm}$ で北 東部に集中しており、不同沈下により被害が発生した。

(2) 杭基礎の被害は、掘出し調查を行ったいずれの杭も杭頭部で圧 壊と曲げひび割れが確認された。また IT 試験とボアホールカメ ラによる調査の結果、被害は杭頭部(GL-6m 以浅)に集中していた。
(3) 杭の引抜き調查の結果、GL-20m 位置に幅 $1 \mathrm{~mm}$ 程度の曲げひび 割れが全周に生じていることを確認した。またひび割れ部分を切 り出した結果、損傷は杭体内部まで進行していることがわかった。

(4) KiK-net による強震記録のシミュレーション解析の結果、地盤応 答は GL-20m 以浅のシルト層で変位が増幅し、地盤剛性は大きく低 下した。地表での観測記録は周期 2 秒付近の振幅が大きく、シミュ レーション結果は良い対応を示した。水平 2 方向同時入力による影 響は、振幅の小さいNS 方向の応答に対して顕著にみられた。

(5) 上部構造の応答は、地盤応答に対応して NS 方向より EW 方向の 応答が大きかった。1階と 2 階が弾性域を若干越えるものの、終局 耐力に比べて応答せん断力は十分小さかった。また杭体の非線形性 は、上部構造の応答に与える影響が小さいことを確認した。

(6) 杭の非線形解析より、杭頭と GL-20m で塑性化が進むこと、また その塑性化状況や損傷の程度が異なることがわかった。また杭頭 は引張軸力時に損傷が進み最終的に圧壊に至ったこと、上部構造 の被害はこの杭頭圧壊に伴う不同沈下で生じたことがわかった。

以上、本研究により、護岸近くなど地盤の残留変形が大きな地点 だけでなく、成層地盤でも本敷地のように軟弱層を有する場合は、 杭基礎の地中部において地震中に被害が生じることを実証すると ともに、被害状況を解析的に確認することができた。

[謝辞]

本研究を実施するに当り、厚真町役場・西尾 茂氏と森本雅彦氏 を始め、同役場の皆様には多大な便宜を図って頂きました。引抜き 調查では、(株)西村建築設計事務所・横井浩明氏と、旭化成建材(株) 渡辺 宏氏にご協力頂きました。また被害調査の実施に当り、鹿島 建設(株)富澤弘幸氏と有江暢亮氏には、全面的に御協力頂きました。 ここに記して感謝の意を表します。

また本論文の作成に当り、東京工業大学・時松孝次教授に御指導 頂きました。ここに記して哚く謝意を表します。

\section{[参考文献]}

1) 鹿島建設(株): 平成 15 年十勝计地震(2003.9.26)被害調査報告書, 2003.10

2) (社)土木学会 : 2003 年十勝沖地震被害調査報告会資料, 2003.11.25

3) (社) 日本建築学会北海道支部：2003 年十勝蚛地震災害調査報告, 2004.5.31

4) (財)震災予防協会 : 2003 年十勝沖地震被害報告, 震災予防, No.194, pp.16-52, 2004.1

5) 鹿岛建設(株): 厚真町厚南中学校 2003 年十勝沖地震による被害調查報 告書, 2003.11.20

6) (独)防災科学技術研究所 : KiK-net HP, http://www.kik.bosai.go.jp

7) (株)狩野重機 : 実用新案登録 第 3101153 号

8) 藤村和也、沖見芳秀 : 液状化解析に用いる 3 次元マルチスプリング モデルの基礎的検討, 土木学会第 55 回年次学術講演会, 2000.9

9) 古山田耕司、宮本裕司、三浦賢治 : 多地点での原位置採取試料から 評価した表層地盤の非線形特性, 地盤工学会研究発表会, pp.2077-2078, 2003

10) 宮本裕司、酒向裕司、古山田耕司、三浦賢治 : 1995 年兵庫県南部地 震の観測記録を用いた液状化地盤における杭基礎構造物の応答に関す る解析的検討, 日本建築学会構造系論文集，第 493 号, pp.23-30, 1997.3 11) (社)建築研究振興協会：常時微動測定による既存建築物の耐震改修効 果確認法指針(案) ・同解説, pp.51-52, 1997

12) Muto K., T. Hisada et al. : Earthquake Resistant Design of a 20 Story Reinforced Concrete Building, 5th World Conference on Earthq. Eng., pp.1960 1969, 1973

13) (社)コンクリートパイル建設技術協会 : 杭計算プログラム COPITA

14）福田孝晴、宮本裕司、古山田耕司：2003 年十勝沖地震での杭被害に 関する解析的検討(その1)扩よび(その2), 日本建築学会大会学術講演梗 概集(北海道) B-2 構造 II , pp.735-738, 2004.8 